numerous others, is so interesting, that he cannot refrain from inserting it. He was called, some few years back, by his friend and former pupil, Mr. John Dobson, then residing at Highgate, to a woman living near Finchley common, who, in several previous and long-protracted labours, had always been delivered by means of the crotchet, in consequence, it was supposed, of a highly-contracted pelvis. She was at her full time, and in addition to the previous supposed difficulty, an arm of the child protruded in front of the head. Two of MIr. Dobson's professional brethren of Highgate had been called in consultation, and when $I$ arrived, one of them had been attempting to return the arm. On examination, the author found the case as described, with the os uteri well dilated; he could not, however, detect any contraction of the pelvis which he deemed incompatible with a natural delivery. His first attention was directed to return the arm, in which he happily succeeded; and then, without removing his finger from the vagina, he commenced stimulating the os uteri, at the same time passing his left hand to the abdomen, upon which he applied vigorous friction and pressure. In little more than a minute a powerful paroxysm of uterine action came on, which drove the head on the perinzeum and partly through the os externum, and the next pain completed the delivery. The cause of protraction in this case, and doubtless in all the preceding ones, was not mechanical, but physical, and depended on principles to be hereafter considered; and this physical cause was immediately removed by acting on the principles of treatment above ad rocated.

In cases of protracted labour from defective uterine energy, the stimulus of the finger, combined with abdominal friction and pressure, will often at once reproduce the full vigour of uterine action; nay, in cases of an apparently unyielding state of the passages, or even of slighter relative disproportion between the pelvis and child's head, they will tend happily to increase the expulsive force, so as to obviate the otherwise probable necessity of having recourse to instrumental means; and lastly, in malking use of instruments, the stimulus which is then necessarily applied will occasionally be the means of inducing such increase of uterine action as to assist, if not supersede, the tractile force.

The whole of the above assertions, strong and novel as they may appear, have not been mere deductions from theory, but have been effectively demonstrated in the author's practice and although many may exclaim against them as instances of "meddlesome midwifery," the treatment recommended, when used with tact, delicacy, and judgment, is not only safe, but capable of abridging materially the sufferings of the patient.

(To be continued.)

\section{POISONING BY STRYCHNIA.}

\section{RECOVERT.}

Bx J. COOPER FORSTER, M.B. Lond., F.R.C.S.

VERY little apolngy is needed, I think, for troubling you with the following interesting case. I am indebted to Mr. WV. C. Hills, house-surgeon to the Surrey Dispensary, who first saw the patient, for the main facts.

S. S-_-, aged fifty-two, a dissolute hypochondriac, with a constitution and intellect considerably damaged, was under my care with indolent ulcers on both legs; and ou account of dyspeptic symptoms, from which he also suffered, I ordered him one-twelfth of a grain of strychnia, to be taken three times a day. For convenience and accuracy in dispensing, an acid solution of strychnia is kept at the Surrey Dispensary, in the proportion of one grain to an ounce of water, and this patient had an ounce and a half of that solution given him, a teaspoonful of which contained the dose required. From inattention to both verbal and printed instructions, on his return home he took rather more than an ounce of the medicine, which he had not swallowed above ten minutes when he became violently convulsed. On discovering his mistake, he immediately took copions dranghts of cold water; but the convulsions increasing in severity, his friends became alarmed and he was driven in a cab to an hospital, when, being refused admittance, he was again brought to the dispensary. An hour and a half had now elapsed since the poison was taken, during the whole of which time his attendant stated he had been violently convulsed. When Mr. Hills first saw him, he had trismus, with the upper and lower extremities completely rigid, and paroxysms of opisthotonos and emprosthotonos occurring alternately. A paroxysm now took place every six minutes, each one lasting about two minutes, and during the emprosthotonic condition he uttered a violent shriek. He had half a drachm of sulphate of zinc given immediately, and was Ir. Hills about four hours after the poison had been taken, and found that he had been slightly emetized by the zinc, and had also been most violently purged. The tetanic rigidity till continued; the paroxysms were, however, less frequent: he patient could only lie on his back, and the slightest exerton brought on the convalsive attacks. The bladder alse seemed to participate in the general contraction of the voluntary muscles, and expelled small quantities of urine, as fast pparently as it flowed into that viscus; the pupils were natural; the pulse small and irritable; and the whole frame was evidently much exhausted and enfeebled. He was now rdered frictions over the spine by means of soap liniment, which afforded him great relief, and half a drachm of the compound spirit of sulphuric ether in camphor mixture to be aken internally every four hours. During the night he continued to have involuntary twitchings of the limbs, which lasted also through the following day; on the second night they became more severe, but were only of a few hours' duration, and then entirely left him. He has since returned to is work in his usual health.

I find Dr. Taylor states, in his valuable work on Poisons, that he has been informed of a case in which a grain of strychnia had been taken, vomiting had supervened, and the patient had recovered; but he does not authenticate it, and moreover states that half a grain proved fatal to Dr. Warner in fourteen minutes. From this, a doubt naturally arises in one's mind, whether the strychuia in the present instance was of good quality, as a dose far beyond the average was swallowed, and in solution, which so much favours absorption; and yet the patient recovered. The extreme urgency of the symptoms, however, I think, sufficiently proves the genuinevess of the drug; and I can therefore only attribute the favourable result to the large quantity of cold water swallowed, which appears to have acted as a nowerful aperient, carrying the poison rapidly along the alimentary canal. With regard to the treatment adopted at the dispensary, it appeared the only course left to be pursucd, as no antidote is known; and the result, I think, proves the value of the zinc administered, and justifies the supposition that this drug acted as a stimulus to the distended intestines to get rid of their contents, as almost immediately after the emetic was swallowed violent purging took place, with only very slight emesis.

Wellington-street, London-bridge, July, 1852.

\section{A Alírror}

OF THE PRACTICE OF

\section{MEDICINE AND SURGERY IN THE \\ HOSPITALS OF LONDON.}

Nulla est alia pro certo noscendi via, nisi quam plurimas et morborum, et dissectionum historias, tum aliorum proprias, colıectas habere et inter se comparare.-Morgagni. De Sed. et Caus. Morb., lib. it. Proomium.

CASES OF ENCEPHALOID DISEASE.

Encephalvid Disfase of the Femur. Mr. Hutow, Guy's Hospital. Mr. Skеу, St. Bartholomew's. ancephaloid Disease of the Fumul- Mr. Johnson, St. George's. Encephatoid Disease of the Femur and Pelvis. Mr. ADAus, London. Encephaloid Disease of the Femur und Ilium Mr. LAWRENCE, St. Bartholomew's Encephuloid Disease of the Humerus, -Mr. STA vis

$$
\begin{aligned}
& \text { Clavicle.-Mr. B. CoOPER, Guy's. " } \\
& \text { Testis.-Mr. CiAnk, St. Thomas's. } \\
& \text { Testis.-Mr. GREen, } \\
& \text { Testis.-Mr. PARTIDGe, King's College. } \\
& \text { Testis.-Mr. JoHnson, St. George's. }
\end{aligned}
$$

\section{ST. BARTHOLOMEW'S HOSPITAL.}

Enceplatoid Disease of the Irumerus; Amputation at the Shoulder-joint.

(Under the care of Mr. StAylex.)

MAVIxG now disposed of the most striking cases of encepha loid disease of the femur, we shall proceed with the remaining cases on our list, and begin with one which offers a good example of encephaloid cancer attacking the humerus.

On the 3rd of May, 1 $\$ 51$, Mary A. W-, aged thirty-nine applied to MIr. Stanley, concerning an affection of the arm 